\title{
ELECTROCHEMICAL PREPARATION OF A MOLECULAR IMPRINTED POLYMER ELECTRODE FOR ESTEMATION OF ASPIRIN USING TWO DIFFERENT FUNCTIONAL MONOMERS.
}

AseelS. Mansoor ${ }^{1}$,Yehya K. Al-Bayati ${ }^{2}$

${ }^{1}$ Assistant Lecturer, Pharmacy Department, Al-Rasheed College University,Iraq. aseel_mansoor@ymail.com

${ }^{2}$ Professor PhD., Chemistry Department, College of Science, University of Baghdad, Iraq. yahyaalbayti@yahoo.com

Received 16/ 8/ 2020, Accepted 19/ 10/ 2020, Published 30/ 6/ 2021

This work is licensed under a CCBY $4.0 \mathrm{https}$ ://creativecommons.org/licenses/by/4.0

\section{ABSTRUCT}

For aspirin estimated, a molecularly imprinted polymer MIP-ASP electrodes were generated by electro-polymerization process, the electrodes were prepared by combining the template (aspirin) with (vinyl acetate (VA), 1-vinylimidizole (VIZ) as a functional monomer and $\mathrm{N}$, N-methylene bisacrylamide (MBAA) as crosslinkers using benzoyl peroxide (BPO) as an initiator. The efficiency of the membrane electrodes was analyzed by differential pulse voltammetry (DPV). Four electrodes were synthesized using two different plasticizers, di-butyl sebacate (DBS), di-octyl phthalate (DOP) in PVC matrix. Scanning electron microscopy (SEM) was used to describe the generated MIP, studying the electrodes properties, the slope, detection limit, and life time and linearity range. The effect of PH and interferes on the efficiency of the MIP electrode was investigated. The study has shown that the molecularly imprinted electrodes have high sensitivity and responsiveness to aspirin. The DPV value was linearly dependence on the aspirin concentration and a linear curve was obtained within the range of $(1 \times 10-1-5 \times 10-4) \mathrm{M}$ of aspirin with correlation coefficients are about $(0.9974,0.9966,0.9938$ and 0.9961$)$ with slops value of $(-21.41,-17.67,-17.47$ and -18.67$)$ and the detection limit for all electrodes ranging from $(7.5 \times 10-5-1 \times 10-4) \mathrm{M}$. The molecularly imprinted electrode exhibited a good response with highly reproducible and no effect on interferes frequently available in pharmaceutical formulations. The approach employed is easy and fast. Also ASP membranes get a limited time of response, excellent mechanical stability, removable and are easy to construct.

Keywords: molecularly imprinted electrochemical sensors (MIECS), Aspirin (ASP), potentiometric method, vinyl acetate (VA) monomer, 1-vinylimidizol (VIZ) monomer. 
Iraqi Journal of Market Research and Consumer Protection

التحضير الكهروكيميائي لقطب بوليمر مطبوع جزيئيا لتقدير الاسبرين وياستخدام وحلتين وظيفيتين مختلفتين

2 اسبيل صلاح منصور ا،يحيى كمال البياتسي

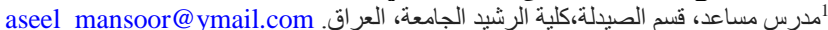

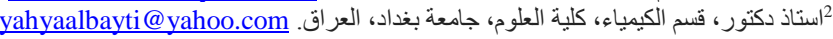

Received 16/ 8/ 2020, Accepted 19/ 10/ 2020, Published 30/ 6/ 2021

This work is licensed under a CCBY 4.0 https://creativecommons.org/licenses/by/4.0

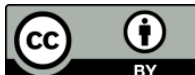

الخلاصة

Electro- تلقدير الأسبرين، تم إنثاء أقطاب بوليمرية مطبوعة جزيئيا polymarization

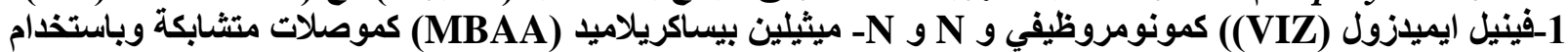

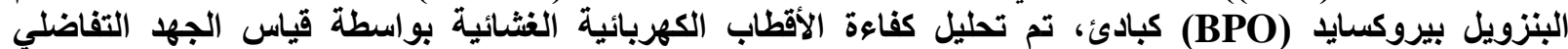

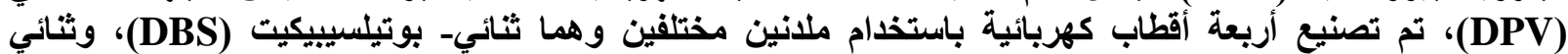

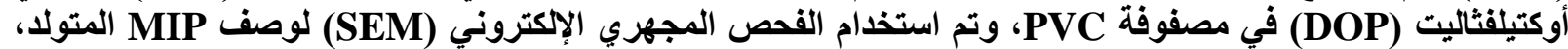

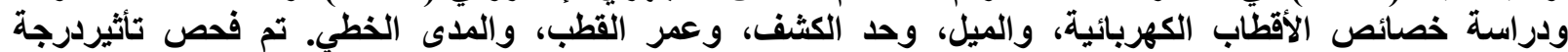

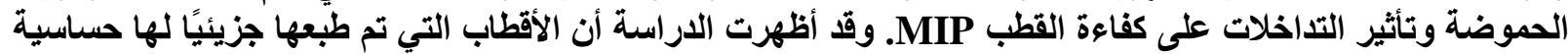

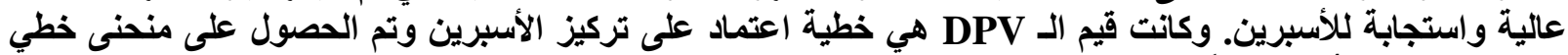

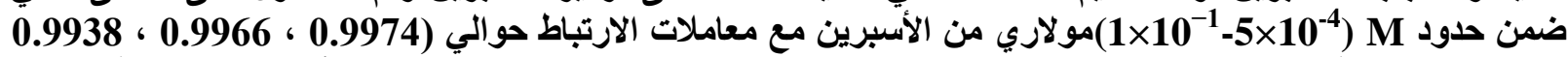

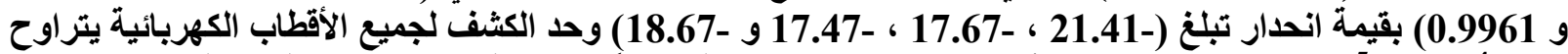
من (4)

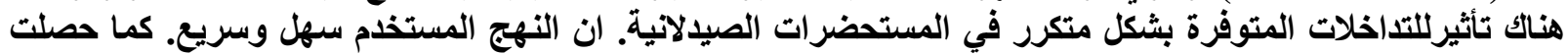

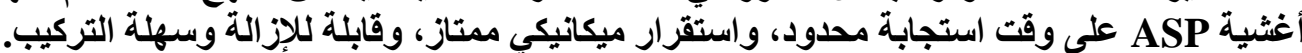

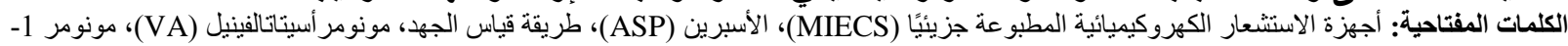

فينيل ايميدزول(VIZ).

\section{INTRODUCTION}

An advance in molecularly imprinted polymers (MIPs) is a useful method to a preparatory work of the polymeric materials with active sites. (Lata et al., 2015). MIPs are polymers that are manufactured to create cavities with attraction to a selected "template" molecule within the polymer chains. They have been prepared by complexing the target (template) with the FM, whether by covalently or non-covalently bonding, accompanied by polymerization with large quantities crosslink's to establish a highly cross linked polymeric network. When the target-molecule is extracted from of the polymeric matrix, different recognizing locations are identified which are comparable to the target in terms of size, shape and function (Meier \& Mizaikoff, 2010). MIPs have been used in various applications, including chromatography ( $\mathbf{L i}$ et $\boldsymbol{a l}$., 2014), capillary electrophoresis chromatography (Rutkowska et al., 2018), quartiz crystals of micro-balance (EL-Sharif et al., 2015), membranes separation (Balouch et al., 2019), SPE (El Nashar et al., 2017; He et al., 2015) and the sensors of biomimetic (Huang et al., 2018; Lahcen \& Amine, 2019; Malitesta et al., 2017). MIPs have several benefits, including high specificity and selectivity to target molecules, greater chemical and mechanical stabilization, insoluble in DW and most organic solvents. In additional, the MIP have easily synthesis and have good mechanical properties, reliability for pressures and temperatures, and thus are cost-effectively and suitable to applicable for harmful chemicals (Al-Bayati \& Aljabari, 2016; N. Zhang et al., 2019)MIPs are the sensing elements of a molecular imprinting electrochemical sensor (MIECS) which are molecularly imprinted. The sensor could specifically recognise of the target molecules depending upon this cavities (active site) in the molecular structure of imprinting polymer. 
Once the template have been extracted, the active site representing the spatial configuration of a target molecules will be obtained as well as the electrochemical response has been received because when MIP is associated with a particular template the electrosignal was recorded depending on the active site, as well as the targeted molecule concentrations can be estimated(Crapnell et al., 2019; Jin et al., 2015; Varghese et al., 2019). MIECS have many characteristic includes: high selectivity, simplest techniques, lower costs, low D.L, highly stable. The combination of both the template molecules and the cavities can also be easily achieved and is carefully applicable even with harmful chemical materials. Thus, MIECS was used for optical and electrochemical applicable (Al-Bayati \& Abd, 2017; Al-Bayati \& AlSafi, 2018; D’Aurelio et al., 2020; Momeneh \& Gholivand, 2018; Tadi \& Motghare, 2016). The utilization of molecular imprinting techniques have increased significantly in recent years, thus illustrating magnificently the ability of MIP model for detection toward the target molecules(Bates et al., 2017; Marć et al., 2018).

As in present study, four of the MIPs have been manufactured as recognizing materials using [Vinylacetate (VA), 1-Vinylimidizol (VIZ)] as functional monomer, N, N-methylene bisacrylamide (MBAA) is a crosslinkers also benzoyl peroxide (BPO) as an initiators using methanol as porogen solvent. The efficiency of the MIPs was tested using rebinding equilibrium assays. The highest efficiency of the MIP was selected as the identification substance in PVC membrane for the estimation of aspirin (ASP) in pharmacological samples.

Aspirin (ASP) is widely used in pharmaceutical formulations as an analgesic and antipyretic agent for relieving headaches, fever, muscle pains and inflammation severe arthritis. so the wide use of ASP had led to the therapeutic intoxication due to overdose, which can be found in individuals with chronic inflammatory diseases and routinely take ASP (Kan et al., 2009; Q. Zhang et al., 2020)(Figure 1) shown the aspirin structure. The aims of this research are studies the response of the MIP-sensor in presence / absences of interferences and record the analysis of the electro-chemical sensors for the estimation of ASP using MIP-sensor electrodes.<smiles>CC(=O)Oc1ccccc1C(C)=O</smiles>

Figure (1): Aspirin structure.

\section{MATERIALS AND METHODS}

The standard of aspirin was gained from of the government drug manufacturer (IRAQSDI-Samara). Aspirin tablets (100 mg) Chewable tablet, acetylsalicylic acid ((SDI)-IRAQ and Memphis/Bayer) were purchased from local pharmacies.Plasticizers: (DBS) (97.0\% purity) and (DOP) (99.5\% purity), were purchased from Sigma Aldrich. Other chemicals and reagents materials were obtained from Fluka, BDH and Sigma Aldrich.

\section{Instruments}

In this work, We use potentiometric measured data by digital voltmeter (PH 211 HANA devices). An analyzer (WTW model, Germany), SCE (Gallenkamp, USA), pH meter (WTW model PH 720, Germany). UV-VIS dual-Beam system (UV-1650 PC) SHIMADZ (Japan), computer interfaced by a SHIMADZU UV investigate system (version 1.10), SHIMADZU FTIR,-8000 (Japan), Scanning Electrons Microscopic (SEM) [JSM-6390A] (Tokyo, Japan) and sensitively balance (Electronically balance ACS120-4 Kern \&Sohn GmbH, Germany). A quality of the electrodes has been monitored by measuring the potential of ASP solutions 
ranging from $5 \times 10^{-5}$ to $1 \times 10^{-1} \mathrm{M}$ at room temperature. The accuracy of electrode activity was measured and then the potential was registered after the internally and externally solution arrived to the equilibration.

\section{Preparation of standard solutions for ISE study}

$100 \mathrm{~mL}$ of $0.1 \mathrm{M}$ standard solution for aspirin was prepared by dissolving $1.802 \mathrm{~g}$ of aspirin in methanol. The ASP solutions ranged from $\left(1 \times 10^{-5}-1 \times 10^{-1}\right) \mathrm{M}$ in $100 \mathrm{~mL}$, also the interferences ion $\left(\mathrm{K}^{+}, \mathrm{Ca}^{+2}, \mathrm{Al}^{+3}\right)$ was prepared ranging from $\left(1 \times 10^{-5}-1 \times 10^{-1}\right) \mathrm{M}$ in $100 \mathrm{~mL}$ volumetric flask and $100 \mathrm{~mL}$ of each (methyl paraben, propyl paraben, tri sodium citrate) interferences solution was prepared from $\left(1 \times 10^{-5}-1 \times 10^{-1}\right) \mathrm{M}$ of a stock solution of $0.1 \mathrm{M}$ interference.

\section{Molecular imprinting polymer synthesis}

The first aspirin molecularly imprinted polymer (ASP-MIP 1 ) prepared by mixed 0.5 mmol $(0.0901 \mathrm{~g})$ from aspirin then mixed with $3 \mathrm{mmol}(0.26 \mathrm{~g})$ vinyl acetate (VA) as the monomer, after that added $15 \mathrm{mmol}(2.313 \mathrm{~g}) \mathrm{N}, \mathrm{N}$-methylene bis-acrylamide (MBAA) to the solution as the cross-linker, followed that added $(0.32 \mathrm{~g})$ benzoyl peroxide as the initiator. All these materials were dissolved in $5 \pm \mathrm{mL}$ methanol $\left(\mathrm{CH}_{3} \mathrm{OH}\right)$ except the initiator have dissolved in $3 \mathrm{Ml}$ chloroform. While the second aspirin molecularly imprinted polymer (ASP-MIP 2$)$ were achieved by mixed $0.4 \mathrm{mmol}(0.0721 \mathrm{~g})$ from aspirin as the template, $2.4 \mathrm{mmol}(0.226 \mathrm{~g}) 1$ vinylimidizol (VIZ) as the monomer, $12 \mathrm{mmol}(1.85 \mathrm{~g}) \mathrm{N}, \mathrm{N}$-methylenbisacrylamide (MBAA) act as crosslinkers also $(0.3 \mathrm{~g})$ benzoyl peroxide as the initiator which dissolved in $5 \mathrm{~mL}$ of methanol $\left(\mathrm{CH}_{3} \mathrm{OH}\right)$. For obtaining a homogeneous solution, the mixture was stirred for 5 minutes. $\mathrm{N}_{2}$ passes for 30 minutes on the mixture to removeoxygenfrom the solution. After that, the solution was put at $60^{\circ} \mathrm{C}$ in a water bath. When the reaction completes the molecularly imprinted polymer became hardened, after the polymerization process the polymer was drying and crashed to obtain a polymer particle. These particles were sonicated in acetonitrile/ $\mathrm{CH}_{3} \mathrm{COOH}(18: 2 \mathrm{v} / \mathrm{v})$ to remove the template from MIP. The polymer was dried for (42-75) hours at room temperature, crushed and ground the polymers by mortar and pestle and sieve to get $125 \mu \mathrm{m}$ particle size (using $125 \mu \mathrm{m}$ mesh sieve); after dried completely at room temp., has been used in the membrane of the selective sensors as an active substance. To fabricate of electrode, The PVC tubing (1-2 cm long) was placed that on a glass slide and soaking it with THF. Similar to an average thickness of the PVC tubing, the membranes also was cut and pasted onto the end tube other end of that was connected to an electrode of $\mathrm{Ag}-\mathrm{AgCl}$.

\section{Preparation of pharmaceutical samples.}

The mortar has used to create the powder of the pharmaceutical tablets. There were two different types of ASP-tablets used it to estimate the molarity concentration of ASP-drugs. An appropriate weight of powder was then taken to prepare of $\left(1 \times 10^{-3}\right.$ and $\left.1 \times 10^{-4}\right) \mathrm{M}$ from the pharmaceutical sample solutions. Suitable quantity of methanol has been used to dissolve pharmaceutical samples and to complete volumes of up to $100 \mathrm{~mL}$.

\section{Scanning Electron Microscope (SEM)}

A morphological characteristics of the MIPs before and after template removal membranes was evaluated by scanning the electron microscope using Tokyo / Japan-JSM-6390 A, in order to show the differences between both the SEM image of both the MIPs before and after the template obtained in proportion to the size and surface morphology of a polymeric particles. SEM analysis indicates that molecular imprinted polymer in surface and in crosssection, had a highly ordered and regular pore structure which serves as the sites of interaction, in (Figure $2 \mathrm{a}$ and $\mathrm{b}$ ) can be seen that micro emulsion polymerization gives very small particles size around $66.8 \mathrm{~nm}$ to $366.7 \mathrm{~nm}$ for Vinyl acetate (VA) polymer and $192.3 \mathrm{~nm}$ to $538.5 \mathrm{~nm}$ for vinylimidizol (VIZ) polymer. 


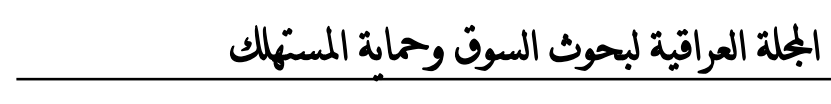

Iraqi Journal of Market Research and Consumer Protection

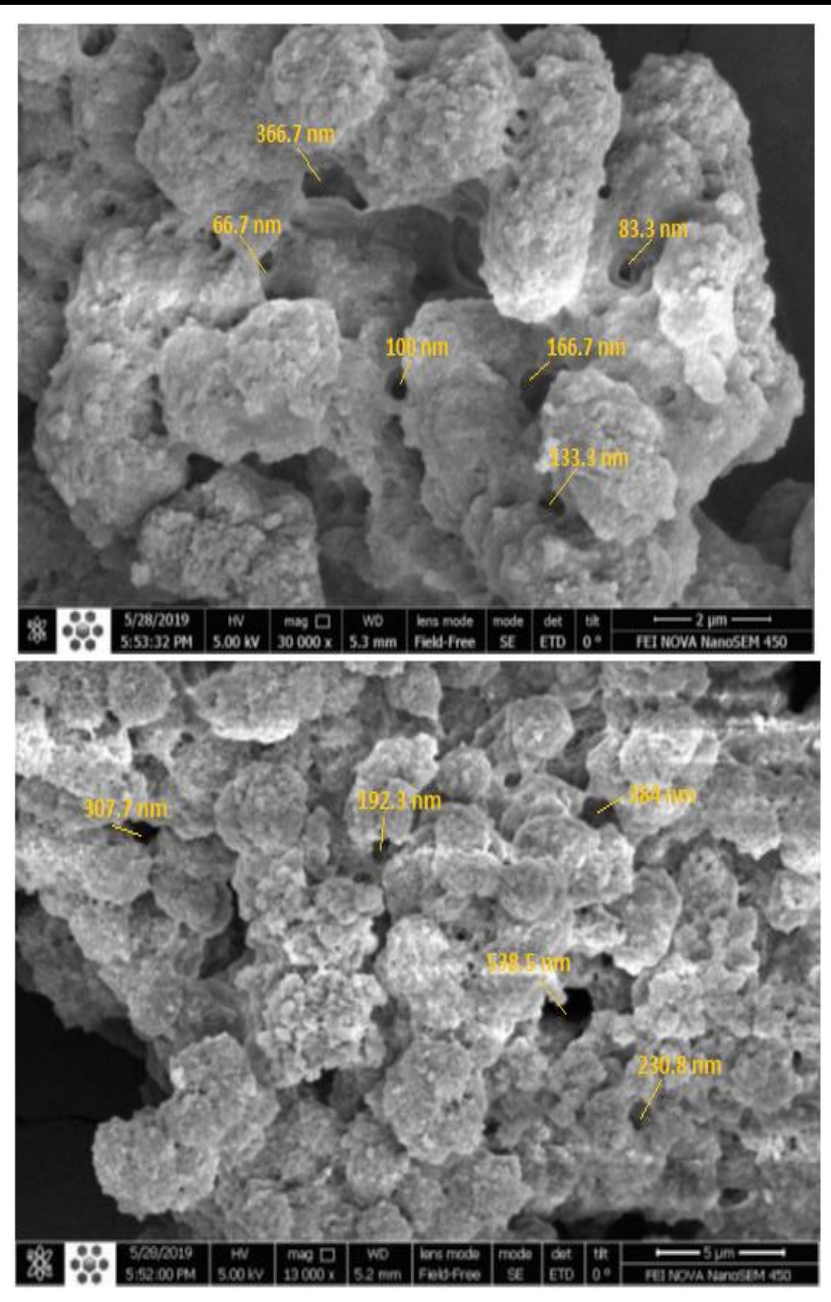

a b

Figure 2: a. SEM of [ASP-MIP(VA)],

b. [ASP-MIP(VIZ)] obtained by bulkpolymerization.

\section{RESULTS AND DISCUSSION}

Four MIP membranes are prepared using two different monomers VA and VIZ with PVC matrix and two different plasticizers DBS and DOP, the ions selective polymer membrane is one of the most crucial components of ISEs. It isolates the internal reference solution from the external analytical sample solution. Polymeric membranes must have selectivity for different analyte ions, un-porous, insoluble in water and mechanically stable, based on the natural of the membrane material used. Other critical components of an ISE assembly are the internally and externally reference electrodes. Collection consisting of both reference electrodes and also the polymeric membrane is referred to as cell the characteristic of these membranes were studied, including: slope, detection limit, linearity, life time and the response to the Nernstian equation were investigated; the results in (Table, 1) indicated that both monomer and both plasticizers can be used for preparing effective MIP for ASP. 
Table (1):The characteristics of ASP-MIP electrode using two different a monomer and two different plasticizer

\begin{tabular}{|c|ccccc|}
\hline \multirow{2}{*}{$\begin{array}{c}\text { Membranes } \\
\text { no. }\end{array}$} & \multirow{2}{*}{$\begin{array}{c}\text { Membrane } \\
\text { composition }\end{array}$} & $\begin{array}{c}\text { Slope } \\
\text { mv/decade }\end{array}$ & $\begin{array}{c}\text { Correlation } \\
\text { coeficien } \\
\text { (r) }\end{array}$ & $\begin{array}{c}\text { Linearity } \\
\text { range (M) }\end{array}$ & $\begin{array}{c}\text { Detection } \\
\text { limit/ M }\end{array}$ \\
\hline I & $\begin{array}{c}\text { ASP-MIP } \\
\text { (VA+MBAA+DBS) }\end{array}$ & -21.41 & 0.9974 & $1 \times 10^{-4}-1 \times 10^{-1}$ & $7.5 \times 10^{-5}$ \\
\hline II & $\begin{array}{c}\text { ASP-MIP } \\
(\text { VA+MBAA+DOP) }\end{array}$ & -17.67 & 0.9966 & $1 \times 10^{-4}-1 \times 10^{-1}$ & $8.0 \times 10^{-5}$ \\
\hline III & $\begin{array}{c}\text { ASP-MIP } \\
(\text { VIZ+MBAA+DBS) }\end{array}$ & -17.47 & 0.9938 & $5 \times 10^{-4}-1 \times 10^{-1}$ & $8.5 \times 10^{-5}$ \\
\hline IV & $\begin{array}{c}\text { ASP-MIP } \\
(\text { VIZ+MBAA+DOP) }\end{array}$ & -18.67 & 0.9961 & $5 \times 10^{-4}-1 \times 10^{-2}$ & $1.0 \times 10^{-4}$ \\
\hline
\end{tabular}

\section{Infrared spectroscopy (FTIR-Analysis)}

The FTIR is a commonly utilized method of substance characterisation. The spectral generated from of the analysis provides the specific samples their identities. The peak frequency of absorption relate to signature vibration of binds between all the atoms that create up the product. The FTIR spectrum is therefore a substance characteristics and allows accurate recognition. The listed in (Table, $2 \& 3$ ) showed a band that before/after removal ASP-template from $\mathrm{MIP}_{1} \& \mathrm{MIP}_{2}$ respectively.

Table (2). The FT-IR spectra for ASP-VA polymer before/after removal clop-template.

\begin{tabular}{|l|lll|}
\hline F.G. & ASP. & $\begin{array}{l}\text { ASP-VA }\left(\mathrm{MIP}_{1}\right) \\
\text { before ASP removal }\end{array}$ & $\begin{array}{l}\text { ASP-VA }\left(\mathrm{MIP}_{1}\right) \\
\text { after ASP removal }\end{array}$ \\
\hline O-H str. & $3200-2500$ & 3384 & 3398 (enol) \\
\hline C-H arom. & 3016 & 3060 & - \\
\hline R-C=O. & 1755 & 1720 & - \\
\hline COOH & 1691 & 1654 & - \\
\hline C=C arom. & 1604 & 1521 & - \\
\hline C=C aliph. & - & - & 1527 \\
\hline COOR & - & 1733 & - \\
\hline
\end{tabular}

From this table can be seen (before ASP removal ) that the characteristically peak at $\sim 1733 \mathrm{~cm}^{-1}$ is attributable to vibrational mode of -COOR and the vibration version of amide N$\mathrm{C}=\mathrm{O}$ is allocated at $\sim 1654 \mathrm{~cm}^{-1}$ these notes indicated to fact that the interaction occurred between the template (ASP) and the monomer (VA), while after ASP removed the detected peak characteristics are missing in carboxylic spectra at $\sim 1654 \mathrm{~cm}^{-1}$, carbonyl group at $\sim 1720$ $\mathrm{cm}^{-1}$ and also missing the absorption band of $\mathrm{C}=\mathrm{C}$ at $\sim 1521 \mathrm{~cm}^{-1}$. The results indicated that the height contrast of imprinted polymer FT-IR spectra before and after template removal proves that ASP-template has been fully extracted from MIP ${ }_{1}$ in the extraction stage by soxhlet. 
Table (3): The FT-IR spectra for ASP-VIZ polymer before/after removal ASP-template

\begin{tabular}{|llll|}
\hline F.G. & ASP. & $\begin{array}{l}\text { ASP-VIZ }\left(\mathrm{MIP}_{2}\right) \\
\text { before ASP rem oval }\end{array}$ & $\begin{array}{l}\text { ASP-VIZ }\left(\mathrm{MIP}_{2}\right) \\
\text { after ASP rem oval }\end{array}$ \\
\hline O-H str. & $3200-2500$ & $3300-3000$ & - \\
\hline C-H arom. & 3016 & 3060 & 3058 \\
\hline C-H aliph & $2974-2833$ & $2952-2866$ & 2948 \\
\hline R-C $=$ O. & 1755 & - & - \\
\hline COOH & 1691 & 1658 & - \\
\hline C $=$ C arom & 1604 & - & 1525 \\
\hline N-C=O & - & 1627 & 1654 \\
\hline
\end{tabular}

The results indicate that the strongest two peaks are missing at $\sim 1691 \mathrm{~cm}^{-1}$ and $\sim 1755$ $\mathrm{cm}^{-1}$ for carbonyl group stretching $\mathrm{C}=\mathrm{O}$ and $\mathrm{C}=\mathrm{C}$ aromatic stretching respectively, while the characteristically peak appears at $\sim 1627 \mathrm{~cm}^{-1}$ due to interaction between the ASP-template and the VIZ-monomer, However when the ASP-template removed after washing noticed that the carbonyl group at $\sim 1658 \mathrm{~cm}^{-1}$ and the hydroxyl group at $\sim 3300 \mathrm{~cm}^{-1}$ are missing, that also indicated the template are completely extracted in the soxhlet extraction stage from $\mathrm{MIP}_{2}$.

\section{Effect of pH on ASP-electrodes}

The $\mathrm{pH}$ dependency of the electrode sensor membrane was measured at a $\mathrm{pH}$ range of $1 \times\left(10^{-4}, 10^{-3}\right.$ and $\left.10^{-2}\right) \mathrm{M}$ aspirin concentrations (Figure 3). PH modifications were made with $(\mathrm{HCl}$ or $\mathrm{NaOH})$ solutions. The results in $(\mathrm{Table}, 4)$, indicate that the potentials slightly change and remain constant from $\sim \mathrm{pH}$ (3.0 to 9.0). Therefore, this range can be considered as the $\mathrm{pH}$ of working electrode senses. The behaviors of this membrane can be explained as follow: a) the $\mathrm{pKa}$ of aspirin is about 3.0, i.e. at acidic $\mathrm{pH}$, observed that the potential will be relatively high at this range; this might be because the membrane can responds to $\mathrm{H}^{+}$activity. b) at higher $\mathrm{pH}$ 9.0, it becomes increasingly dissociated for this explanation we have noticed a decline in potential.

Table (4): Effective $\mathrm{pH}$ ranges used for ASP-selective electrodes.

\begin{tabular}{|c|c|c|c|c|}
\hline \multirow{2}{*}{$\begin{array}{c}\text { Membranes } \\
\text { no. }\end{array}$} & \multirow[b]{2}{*}{$\begin{array}{l}\text { Membrane } \\
\text { composition }\end{array}$} & \multicolumn{3}{|c|}{ PH rang } \\
\hline & & $1 \times 10^{-2}$ & $1 \times 10^{-3}$ & $1 \times 10^{-4}$ \\
\hline I & $\begin{array}{c}\text { ASP-MIP } 1 \\
(\mathrm{VA}+\mathrm{MBAA}+\mathrm{DBS})\end{array}$ & $2.5-9.0$ & $3.0-8.5$ & $2.5-9.5$ \\
\hline II & $\begin{array}{c}\text { ASP-MIP } 1 \\
(\mathrm{VA}+\mathrm{MBAA}+\mathrm{DOP})\end{array}$ & $3.0-9.0$ & $2.5-9.5$ & $4.0-9.5$ \\
\hline III & $\begin{array}{c}\text { ASP-MIP }_{2} \\
\text { (VIZ+MBAA+DBS) }\end{array}$ & $3.5-9.0$ & $3.0-9.0$ & $3.5-10.0$ \\
\hline IV & $\begin{array}{c}\text { ASP-MIP }_{2} \\
\text { (VIZ+MBAA+DOP) }\end{array}$ & $3.0-9.5$ & $2.5-9.5$ & $3.0-9.0$ \\
\hline
\end{tabular}

\section{Selectivity of ASP-electrodes potentiometric}

The influence of interferences on the electrods-response behavior is usually described as the selectivity coefficients. So the $\mathrm{K}_{\text {pot }}$ selectivity coefficient of MIP-sensor's was analyzed using the separation solution method (SSM) and Matched Potential Method (MPM). The measured by SSM methods depend on equation of the Nickolsky-Eisenman but the SSM methods does have some disadvantages in line with interference ions (unequal charges) with non-Nernstainbehavior. Thus, a similar procedure referred to as [Matched Potential Method (MPM)] was preferred, in specific, as the primary or interference ion does not obey on the 
Nernst response, or when the ions concerned is different in charge. As seen from results in (Table 5 and 6) the selectivity coefficients achieved for all prepared electrode sensors, that most of these compounds did not interfere with the response of the electrode sensors membrane.

Table (5): Result of selectivity coefficients for some interfering species using SSM for MIP 1 with different plasterer.

\begin{tabular}{|c|c|c|c|c|c|c|c|c|c|c|c|c|c|c|}
\hline \multirow{4}{*}{ 总 } & \multicolumn{14}{|c|}{ Concentrations of Aspirin (MIPI+DBS) M: Concentrations of interference ions (M) } \\
\hline & \multicolumn{2}{|c|}{0.1} & \multicolumn{2}{|c|}{0.01} & \multicolumn{2}{|c|}{0.005} & \multicolumn{2}{|c|}{0.001} & \multicolumn{2}{|c|}{0.0005} & \multicolumn{2}{|c|}{0.0001} & \multicolumn{2}{|c|}{0.00005} \\
\hline & $\mathrm{E}_{\mathrm{B}}$ & 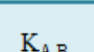 & $\mathrm{E}_{\mathrm{B}}$ & 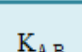 & $\mathrm{E}_{\mathrm{B}}$ & 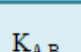 & $E_{B}$ & 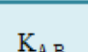 & $E_{B}$ & $\mathrm{~K}_{\mathrm{B}}$ & $E_{B}$ & $\mathrm{~K}_{\mathrm{AB}}$ & $\mathrm{E}_{\mathrm{B}}$ & $\mathrm{K}_{\mathrm{A}}$ \\
\hline & $(\mathrm{mV})$ & $\mathrm{K}_{\mathrm{A}, \mathrm{B}}$ & $(\mathrm{mV})$ & $\mathrm{K}_{\mathrm{A}, \mathrm{B}}$ & $(\mathrm{mV})$ & $\mathrm{K}_{\mathrm{A}, \mathrm{B}}$ & $(\mathrm{mV})$ & $\mathrm{K}_{\mathrm{A}, \mathrm{B}}$ & $(\mathrm{mV})$ & & $(\mathrm{mV})$ & $\mathrm{K}_{\mathrm{A}, \mathrm{B}}$ & $(\mathrm{mV})$ & $\mathrm{K}_{\mathrm{A}, \mathrm{B}}$ \\
\hline $\mathrm{K}^{+}$ & -151.4 & 0.0078 & -146.8 & 0.041 & -143.2 & 0.0433 & -136.6 & 0.131 & -132.2 & 0.197 & -127.4 & 0.502 & -124.3 & 0.781 \\
\hline $\mathrm{Ca}^{2+}$ & -157.1 & 0.0046 & -150.4 & 0.006 & -149.3 & 0.0059 & -147.9 & 0.014 & -144.1 & 0.016 & -142.5 & 0.025 & -138.2 & 0.025 \\
\hline $\mathrm{Al}^{3+}$ & -156.3 & 0.0029 & -153.2 & 0.0038 & -152.6 & 0.0035 & -150.1 & 0.0056 & -148.7 & 0.007 & -147.3 & 0.009 & -145.8 & 0.011 \\
\hline M.P. & -131.7 & 0.0009 & -130.5 & 0.0071 & -129.4 & 0.0098 & -127.6 & 0.0498 & -127.3 & 0.116 & -126.7 & 0.466 & -126.4 & 0.979 \\
\hline P.P. & -133.8 & 0.0012 & -131.6 & 0.008 & -130.4 & 0.0109 & -128.9 & 0.0572 & -126.6 & 0.108 & -124.2 & 0.356 & -120.5 & 0.519 \\
\hline T.S.C. & -134.6 & 0.0003 & -133.9 & 0.0005 & -133.2 & 0.0004 & -132.5 & 0.0008 & -131.7 & 0.001 & -129.7 & 0.001 & -129 & 0.002 \\
\hline \multirow{4}{*}{ 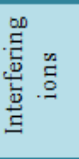 } & \multicolumn{14}{|c|}{ Concentrations of Aspirin (MIPI+DOP) M: Concentrations of interference ions (M) } \\
\hline & \multicolumn{2}{|c|}{0.1} & \multicolumn{2}{|c|}{0.01} & \multicolumn{2}{|c|}{0.005} & \multicolumn{2}{|c|}{0.001} & \multicolumn{2}{|c|}{0.0005} & \multicolumn{2}{|c|}{0.0001} & \multicolumn{2}{|c|}{0.00005} \\
\hline & $\mathrm{E}_{\mathrm{B}}$ & & $\mathrm{E}_{\mathrm{B}}$ & & $\mathrm{E}_{\mathrm{B}}$ & & $E_{B}$ & & $\mathrm{E}_{\mathrm{B}}$ & & $\mathrm{E}_{\mathrm{B}}$ & & $\mathrm{E}_{\mathrm{B}}$ & \\
\hline & $(\mathrm{mV})$ & & $(\mathrm{mV})$ & $\mathrm{K}_{\mathrm{A}, \mathrm{B}}$ & $(\mathrm{mV})$ & $\mathbf{\Lambda}_{\mathrm{A}, \mathrm{B}}$ & $(\mathrm{mV})$ & & $(\mathrm{mV})$ & & $(\mathrm{mV})$ & & $(\mathrm{mV})$ & \\
\hline $\mathrm{K}^{+}$ & -241.4 & 0.0105 & -239.2 & 0.071 & -238.8 & 0.194 & -223.4 & 0.0996 & -220.1 & 0.174 & -219.7 & 0.617 & -217.5 & 0.878 \\
\hline $\mathrm{Ca}^{2+}$ & -238.7 & 0.0023 & -236.4 & 0.005 & -234.1 & 0.007 & -231.8 & 0.0094 & -230.3 & 0.015 & -229.6 & 0.022 & -226.4 & 0.02 \\
\hline $\mathrm{Al}^{3+}$ & -235.5 & 0.001 & -232.1 & 0.001 & -230.4 & 0.002 & -229.4 & 0.0022 & -226.1 & 0.002 & -225.5 & 0.003 & -224.7 & 0.003 \\
\hline M.P. & -231.7 & 0.003 & -229.4 & 0.02 & -226.4 & 0.038 & -224.1 & 0.1091 & -221.9 & 0.221 & -217.7 & 0.476 & -214.2 & 0.571 \\
\hline P.P. & -230.7 & 0.0026 & -227.4 & 0.015 & -225.3 & 0.033 & -221.8 & 0.0809 & -220.7 & 0.189 & -217.5 & 0.464 & -215.8 & 0.703 \\
\hline T.S.C. & -233.7 & 0.0008 & -230.1 & 0.001 & -225.5 & 0.001 & -224.3 & 0.0011 & -221.2 & 0.001 & -219.8 & 0.001 & -219.1 & 0.001 \\
\hline
\end{tabular}

Table (6). Result of selectivity coefficients for some interfering species using SSM for $\mathrm{MIP}_{2}$ with different plasterer.

\begin{tabular}{|c|c|c|c|c|c|c|c|c|c|c|c|c|c|c|}
\hline \multirow{3}{*}{ 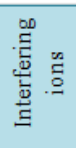 } & \multicolumn{14}{|c|}{ Concentrations of Aspirin (MIP2+DBS) M: Concentrations of interference ions (M) } \\
\hline & \multicolumn{2}{|c|}{0.1} & \multicolumn{2}{|c|}{0.01} & \multicolumn{2}{|c|}{0.005} & \multicolumn{2}{|c|}{0.001} & \multicolumn{2}{|c|}{0.0005} & \multicolumn{2}{|c|}{0.0001} & \multicolumn{2}{|c|}{0.00005} \\
\hline & $\frac{E_{\mathrm{B}}}{(\mathrm{mV})}$ & $\mathrm{K}_{\mathrm{A}, \mathrm{B}}$ & $\frac{E_{B}}{(m V)}$ & $\mathrm{K}_{\mathrm{A}, \mathrm{B}}$ & $\frac{\mathrm{E}_{\mathrm{B}}}{(\mathrm{mV})}$ & $\mathrm{K}_{\mathrm{A}, \mathrm{B}}$ & $\frac{E_{B}}{(m V)}$ & $\mathrm{K}_{\mathrm{A}, \mathrm{B}}$ & $\frac{E_{\mathrm{B}}}{(\mathrm{mV})}$ & $\mathrm{K}_{\mathrm{A}, \mathrm{B}}$ & $\frac{\mathrm{E}_{\mathrm{B}}}{(\mathrm{mV})}$ & $\mathrm{K}_{\mathrm{A}, \mathrm{B}}$ & $\frac{\mathrm{E}_{\mathrm{B}}}{(\mathrm{mV})}$ & $\mathrm{K}_{\mathrm{A}, \mathrm{B}}$ \\
\hline $\mathrm{K}^{+}$ & -90 & 0.0007 & -54.3 & $5 \times 10^{-5}$ & -35.7 & $6 \times 10^{-6}$ & -28.2 & $1.5 \times 10^{-5}$ & -22.4 & $1 \times 10^{-5}$ & -21.5 & $6 \times 10^{-5}$ & -16.6 & $9 \times 10^{-5}$ \\
\hline $\mathrm{Ca}^{2+}$ & -81.1 & $7 \times 10^{-5}$ & -63.4 & $2 \times 10^{-5}$ & -40 & $8 \times 10^{-7}$ & -23 & $2.4 \times 10^{-7}$ & -24.6 & $4 \times 10^{-7}$ & -24.5 & $9 \times 10^{-7}$ & -21.7 & $1 \times 10^{-6}$ \\
\hline $\mathrm{Al}^{3+}$ & -73.6 & $2 \times 10^{-5}$ & -50.6 & $1 \times 10^{-6}$ & -48.1 & $9 \times 10^{-7}$ & -42.4 & $9.6 \times 10^{-7}$ & -37.9 & $6 \times 10^{-7}$ & -31.3 & $5 \times 10^{-5}$ & -29.7 & $7 \times 10^{-7}$ \\
\hline M.P. & 101.2 & 03 & -85.3 & 003 & -84.2 & 0.0036 & -75.5 & 0.00752 & -71.4 & .0082 & -63.6 & 55 & -61.8 & .0347 \\
\hline P.P. & -79.8 & 0002 & -70.4 & 0004 & -67.5 & 0.0004 & -60.2 & 0.001 & -54 & 0.0009 & -51.5 & 0.0032 & -49.7 & 0.007 \\
\hline T.S.C. & -79.6 & $4 \times 10^{-5}$ & -70.6 & $2 \times 10^{-5}$ & -64.1 & $7 \times 10^{-6}$ & -55.4 & $5.3 \times 10^{-6}$ & -50.9 & $3 \times 10^{-6}$ & -45.3 & $3 \times 10^{-6}$ & -41.2 & $3 \times 10^{-6}$ \\
\hline \multirow{3}{*}{ 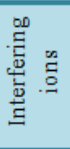 } & \multicolumn{14}{|c|}{ Concentrations of Aspirin (MIP2+DOP) M: Concentrations of interference ions (M) } \\
\hline & & \multicolumn{2}{|c|}{0.01} & \multicolumn{2}{|c|}{0.005} & \multicolumn{2}{|c|}{0.001} & \multicolumn{2}{|c|}{0.0005} & \multicolumn{2}{|c|}{0.0001} & \multicolumn{2}{|c|}{0.00005} \\
\hline & $\frac{E_{B}}{(m V)}$ & $\mathrm{K}_{\mathrm{A}, \mathrm{B}}$ & $\frac{E_{B}}{(m V)}$ & $\mathrm{K}_{\mathrm{A}, \mathrm{B}}$ & $\frac{E_{B}}{(m V)}$ & $\mathrm{K}_{\mathrm{A}, \mathrm{B}}$ & $\frac{\mathrm{E}_{\mathrm{B}}}{(\mathrm{mV})}$ & $\mathrm{K}_{\mathrm{A}, \mathrm{B}}$ & $\frac{\mathrm{E}_{\mathrm{B}}}{(\mathrm{mV})}$ & $\mathrm{K}_{\mathrm{A}, \mathrm{B}}$ & $\frac{\mathrm{E}_{\mathrm{B}}}{(\mathrm{mV})}$ & $\mathrm{K}_{\mathrm{A}, \mathrm{B}}$ & $\frac{\mathrm{E}_{\mathrm{B}}}{(\mathrm{mV})}$ & $\mathrm{K}_{\mathrm{A}, \mathrm{B}}$ \\
\hline $\mathrm{K}^{+}$ & -112.8 & $8.7 \times 10^{-8}$ & -93.9 & $9.6 \times 10^{-8}$ & -91.1 & $8.5 \times 10^{-8}$ & -85.7 & $2.8 \times 10^{-7}$ & -84.2 & $6.1 \times 10^{-7}$ & -80.7 & $1.5 \times 10^{-6}$ & -77.3 & $2.1 \times 10^{-6}$ \\
\hline $\mathrm{Ca}^{2+}$ & -116.3 & $4.2 \times 10^{-8}$ & -106 & $4.3 \times 10^{-8}$ & -105 & $3.3 \times 10^{-8}$ & -101.2 & $6.0 \times 10^{-8}$ & -97.8 & $7.2 \times 10^{-8}$ & -95.5 & $9.4 \times 10^{-8}$ & -92.5 & $9.8 \times 10^{-8}$ \\
\hline $\mathrm{Al}^{3+}$ & -119.7 & $4.4 \times 10^{-8}$ & -116.1 & $6.9 \times 10^{-8}$ & -115.8 & $5.2 \times 10^{-8}$ & -110.3 & $5.8 \times 10^{-8}$ & -109.6 & $8.73 \times 10^{-8}$ & -109 & $1.1 \times 10^{-7}$ & -107.4 & $1.2 \times 10^{-7}$ \\
\hline M.P. & -163.9 & $4.8 \times 10^{-5}$ & -157.8 & 0.00025 & -154.3 & 0.00021 & -153.2 & 0.00116 & -151.7 & 0.002494 & -144.6 & 0.004034 & -139.8 & 0.00474 \\
\hline P.P. & -166.5 & $6.6 \times 10^{-5}$ & -161.2 & 0.00039 & -160.7 & 0.00045 & -159 & 0.00237 & -155.3 & 0.003888 & -153.2 & 0.011652 & -150.4 & 0.01751 \\
\hline T.S.C. & -151.3 & $2.2 \times 10^{-6}$ & -148.7 & $3.8 \times 10^{-6}$ & -148.2 & $2.8 \times 10^{-6}$ & -142.9 & $3.3 \times 10^{-6}$ & -143.9 & $6.0 \times 10^{-6}$ & -141.2 & $5.7 \times 10^{-6}$ & -140.5 & $7.0 \times 10^{-6}$ \\
\hline
\end{tabular}

\section{Analysis of commercial tablets}

In order to illustrate the technical use of the electrochemical sensor, two tablets for (ASP) were analyzed by MIP electrodes. The solutions was obtained by dissolving the specific 
weight of commercial tablets in methanol solvent and diluted so that the tablet concentration range lies within calibration plot values. The DPVs value then was recorded under precisely the same conditions. The suggested technique was used to measure the concentration of all selected drugs in two types of pharmaceutical products. In order to verify the electro-chemical detection, we have compartmented the data results for parameters RSD\%, RC\% and Erel\% with both detection methods including: direct potentiometric, standard addition method (SAM), multi standard addition method (MSA), by using ISE, as well as titration method and optimal chromatographic conditions. The results was indicated in (Table, $7 \& 8$ )

Table (7). Recovery results and standard deviation of ASP-drugs obtained through the use of (MIP1+DBS).

\begin{tabular}{|c|c|c|c|c|c|c|}
\hline Drug & $\begin{array}{r}\text { Concentration } \\
\text { Prepared/ M }\end{array}$ & $\begin{array}{c}\text { Potentiometric } \\
\text { methods }\end{array}$ & $\begin{array}{c}\text { Concentration } \\
\text { Found/ } \mathrm{M} \\
\end{array}$ & \%Rec. & $\% R E$ & \%RSD \\
\hline \multirow{6}{*}{$\begin{array}{l}\text { Aspirin } \\
\text { material }\end{array}$} & \multirow{3}{*}{$1 \times 10^{-3}$} & Direct method & $1.0312 \times 10^{-3}$ & 103.1 & 3.12 & 2.31 \\
\hline & & SAM & $1.0556 \times 10^{-3}$ & 103.22 & 3.22 & 2.07 \\
\hline & & MSM & $1.0402 \times 10^{-3}$ & 104.02 & 4.02 & 0.41 \\
\hline & \multirow{3}{*}{$1 \times 10^{-4}$} & Direct method & $1.0300 \times 10^{-4}$ & 103.15 & 3.15 & 1.55 \\
\hline & & SAM & $1.0455 \times 10^{-4}$ & 103.41 & 3.41 & 1.1 \\
\hline & & MSM & $1.0356 \times 10^{-4}$ & 103.56 & 3.56 & 0.22 \\
\hline \multirow{6}{*}{$\begin{array}{l}\text { Chewable tablet, } \\
\text { acetylsalicylic acid } \\
\text { (SDI)-IRAQ }\end{array}$} & \multirow{3}{*}{$1 \times 10^{-3}$} & Direct method & $1.0343 \times 10^{-3}$ & 103.42 & 3.42 & 0.92 \\
\hline & & SAM & $1.0554 \times 10^{-3}$ & 104.39 & 4.39 & 0.95 \\
\hline & & MSM & $1.0332 \times 10^{-3}$ & 103.32 & 3.32 & 0.33 \\
\hline & \multirow{3}{*}{$1 \times 10^{-4}$} & Direct method & $1.0279 \times 10^{-4}$ & 102.79 & 2.79 & 0.77 \\
\hline & & SAM & $1.0687 \times 10^{-4}$ & 104.57 & 4.57 & 2.2 \\
\hline & & MSM & $1.0310 \times 10^{-4}$ & 103.1 & 3.1 & 0.23 \\
\hline \multirow{6}{*}{$\begin{array}{l}\text { acidumacetylsaicylic } \\
\text { um, Memphis/Bayer }\end{array}$} & \multirow{3}{*}{$1 \times 10^{-3}$} & Direct method & $1.0311 \times 10^{-3}$ & 103.12 & 3.11 & 1.4 \\
\hline & & SAM & $1.0541 \times 10^{-3}$ & 104.06 & 4.06 & 1.3 \\
\hline & & MSM & $1.0394 \times 10^{-3}$ & 103.94 & 3.94 & 0.26 \\
\hline & \multirow{3}{*}{$1 \times 10^{-4}$} & Direct method & $1.0315 \times 10^{-4}$ & 103.15 & 3.15 & 1.55 \\
\hline & & SAM & $1.0526 \times 10^{-4}$ & 103.74 & 3.74 & 1.68 \\
\hline & & MSM & $1.0353 \times 10^{-4}$ & 103.53 & 3.53 & 0.34 \\
\hline
\end{tabular}

Table (8). Recovery results and standard deviation of ASP-drugs obtained through the use of (MIP2+DBS).

\begin{tabular}{|c|c|c|c|c|c|c|}
\hline Drug & $\begin{array}{r}\text { Concentration } \\
\text { Prepared/ M }\end{array}$ & $\begin{array}{c}\text { Potentiometric } \\
\text { methods }\end{array}$ & $\begin{array}{c}\text { Concentration } \\
\text { Found/ M }\end{array}$ & \%Rec. & $\%$ RE & \%RSD \\
\hline \multirow{6}{*}{$\begin{array}{l}\text { Aspirin } \\
\text { material }\end{array}$} & \multirow{3}{*}{$1 \times 10^{-3}$} & Direct method & $1.0378 \times 10^{-3}$ & 103.78 & 3.78 & 1.71 \\
\hline & & SAM & $1.0528 \times 10^{-3}$ & 102.55 & 2.55 & 2.44 \\
\hline & & MSM & $1.0367 \times 10^{-3}$ & 103.67 & 3.67 & 0.48 \\
\hline & \multirow{3}{*}{$1 \times 10^{-4}$} & Direct method & $1.0370 \times 10^{-4}$ & 103.69 & 3.69 & 2.19 \\
\hline & & SAM & $1.0383 \times 10^{-4}$ & 102.42 & 2.42 & 1.79 \\
\hline & & MSM & $1.0260 \times 10^{-4}$ & 102.6 & 2.6 & 0.41 \\
\hline \multirow{6}{*}{$\begin{array}{l}\text { Chewable tablet, } \\
\text { acetylsalicylic acid } \\
\text { (SDI)-IRAQ }\end{array}$} & \multirow{3}{*}{$1 \times 10^{-3}$} & Direct method & $1.0451 \times 10^{-3}$ & 104.51 & 4.51 & 0.68 \\
\hline & & SAM & $1.0698 \times 10^{-3}$ & 104.2 & 4.2 & 2.44 \\
\hline & & MSM & $1.0323 \times 10^{-3}$ & 103.23 & 3.23 & 0.49 \\
\hline & \multirow{3}{*}{$1 \mathrm{X} 10^{-4}$} & Direct method & $1.0450 \times 10^{-4}$ & 104.53 & 4.53 & 1.51 \\
\hline & & $\mathrm{SAM}$ & $1.0498 \times 10^{-4}$ & 102.89 & 2.89 & 1.79 \\
\hline & & MSM & $1.0262 \times 10^{-4}$ & 102.62 & 2.62 & 0.41 \\
\hline \multirow{6}{*}{$\begin{array}{l}\text { acidumacetylsaicylic } \\
\text { um, Memphis/Bayer }\end{array}$} & \multirow{3}{*}{$1 \mathrm{X} 10^{-3}$} & Direct method & $1.0456 \times 10^{-3}$ & 104.56 & 4.56 & 1.73 \\
\hline & & SAM & $1.0586 \times 10^{-3}$ & 103.77 & 3.77 & 2 \\
\hline & & MSM & $1.0376 \times 10^{-3}$ & 103.76 & 3.76 & 0.4 \\
\hline & \multirow{3}{*}{$1 \mathrm{X} 10^{-4}$} & Direct method & $1.0480 \times 10^{-4}$ & 104.81 & 4.81 & 1.92 \\
\hline & & SAM & $1.0626 \times 10^{-4}$ & 104.54 & 4.54 & 2.02 \\
\hline & & MSM & $1.0324 \times 10^{-4}$ & 103.24 & 3.24 & 0.47 \\
\hline
\end{tabular}




\section{Adsorption Isotherm}

Adsorption isotherm is useful in understanding the adsorption mechanism of the adsorption template on a polymer surface. The collected data from the adsorption isotherm equilibrium were studied to illustrate the isotherm model Langmuir or Freundlich this was accomplished by plotting the ability of binding (Q) against free drug concentration, Q is determined according to the equation below: Adsorption isotherm produced after preparation of different concentrations of standard solution at room temperature is shown in (Figure,3). Experimental results for classifying experiments have been included in the (Table, 9).

Table (9). Rebinding values of (ASP) using [ASP - MIP 1 ] particles based on (VA).

\begin{tabular}{|c|c|c|c|c|}
\hline \multirow[b]{2}{*}{$\begin{array}{l}\text { Mass of } \\
\text { MIP g }\end{array}$} & \multicolumn{4}{|c|}{$\left[A S P-M I P_{1}(V A)\right]$} \\
\hline & $\begin{array}{l}\mathrm{Ci} \\
\mathrm{mM}\end{array}$ & $\begin{array}{l}\mathrm{C}_{\text {free }} \\
\mathbf{m M}\end{array}$ & $\begin{array}{l}\mathrm{Q} \\
\boldsymbol{\mu M} \text { Mle } \\
/ \mathrm{g}\end{array}$ & $\begin{array}{l}Q / C_{\text {fee }} \\
\mathrm{L} / \mathrm{g}\end{array}$ \\
\hline \multirow{3}{*}{0.05} & 0.111 & 0.10866 & 0.4671 & 4.29825 \\
\hline & 0.222 & 0.2181 & 0.7802 & 3.57724 \\
\hline & 0.333 & 0.32494 & 1.6113 & 4.95868 \\
\hline \multirow{3}{*}{0.1} & 0.111 & 0.10996 & 0.1043 & 0.94862 \\
\hline & 0.222 & 0.21517 & 0.6834 & 3.17604 \\
\hline & 0.333 & 0.31741 & 1.5592 & 4.91228 \\
\hline
\end{tabular}
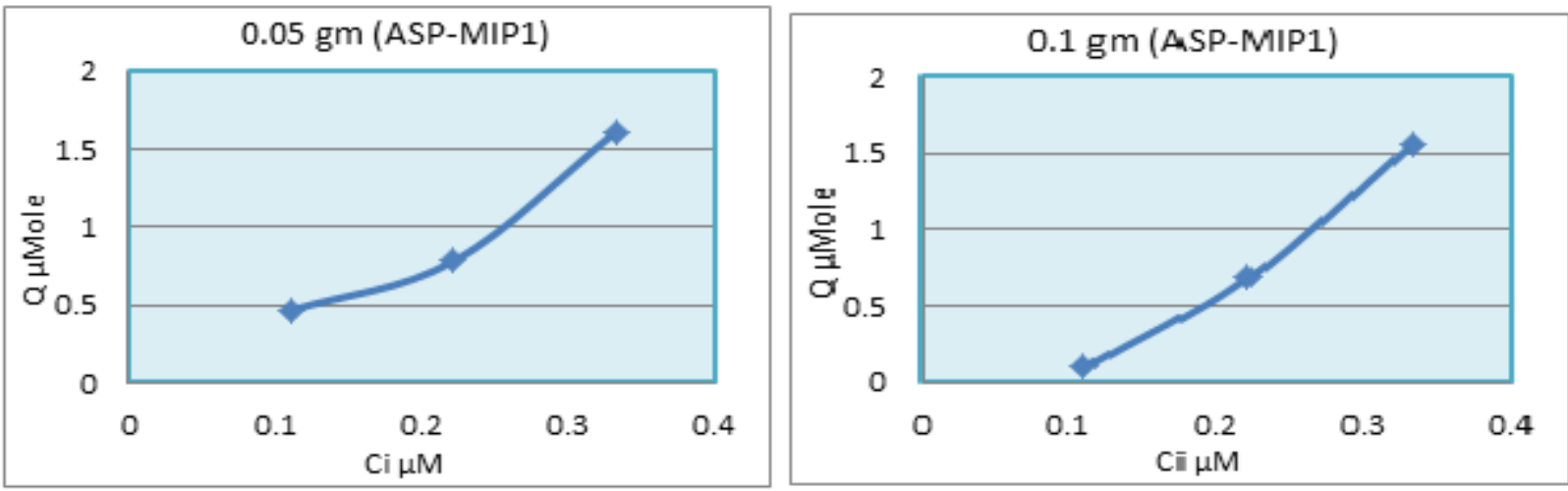

Figure (3): Binding isotherm of (ASP - MIP 1 ) using VA as monomers.

\section{CONCLUSION}

In this research, four electrodes were prepared based on MIP method using two monomer (VA, VIZ) and two different plasticizer (DBS, DOP), as it was observed that the interaction between template and the monomer was non-covently, therefore the ASP-drug was extracted easily to form selective cavity for estimation commercial ASP and excellent results obtained at lowest costs and with high accuracy.

\section{REFERENCES}

1. Al-Bayati, Y. K. \& Abd, M. F. (2017). Determination of methamphetamine drug by GC-MS based on molecularly imprinted solid-phase used meth acrylic acid and acryl amide as functional monomers. Iraqi Journal of Science,58(4B), 2022-2034.

2. Al-Bayati, Y. K. \& Al-Safi, A. J. (2018). Synthesis and characterization of a molecularly imprinted polymer for diclofenac sodium using (2-vinylpyridine and 2-hydroxyethyl metha acrylate) as the complexing monomer. Baghdad Science Journal,15(1), 63-72. 
3. Al-Bayati, Y. K. \& Aljabari, F. I. (2016). Synthesis of Ibuprofen-molecularly imprinted polymers used as sensors to determine drug in pharmaceutical preparations. Asian Journal of Chemistry, 28(6), 1376-1384.

4. Balouch, A., Talpur, F. N., Kumar, A., Shah, M. T. \& Mahar, A. M. (2019). Synthesis of ultrasonic-assisted lead ion imprinted polymer as a selective sorbent for the removal of $\mathrm{Pb}^{2+}$ in a real water sample. Microchemical Journal, 146, 1160-1168.

5. Bates, F., Busato, M., Piletska, E., Whitcombe, M. J., Karim, K. \& Guerreiro, A. (2017). Computational design of molecularly imprinted polymer for direct detection of melamine in milk. Separation Science Technology, 52(8), 1441-1453.

6. Crapnell, R. D., Hudson, A., Foster, C. W., Eersels, K., Grinsven, B., \& Cleij, T. J. (2019). Recent advances in electrosynthesized molecularly imprinted polymer sensing platforms for bioanalyte detection. Sensors, 19(5), 1204-1210.

7. D'Aurelio, R., Chianella, I., Goode, J. A. \& Tothill, I. E. (2020). Molecularly imprinted nanoparticles based sensor for cocaine detection. Biosensors, 10(3), 22-30.

8. EL-Sharif, H. F., Aizawa, H. \& Reddy, S. M. (2015). Spectroscopic and quartz crystal microbalance (QCM) characterisation of protein-based MIPs. Sensors Actuators B: Chemical, 206, 239-245.

9. El Nashar, R. M., Ghani, N. T. A., El Gohary, N. A., Barhoum, A. \& Madbouly, A. (2017). Molecularly imprinted polymers based biomimetic sensors for mosapride citrate detection in biological fluids. Materials Science Engineering: C, 76, 123-129.

10. He, J., Liu, A. \& Chen, J. P. (2015). Introduction and demonstration of a novel Pb (II)imprinted polymeric membrane with high selectivity and reusability for treatment of lead contaminated water. Journal of Colloid Interface Science, 439, 162-169.

11. Huang, J., Wu, Y., Cong, J., Luo, J. \& Liu, X. J. (2018). Selective and sensitive glycoprotein detection via a biomimetic electrochemical sensor based on surface molecular imprinting and boronate-modified reduced graphene oxide. Sensors Actuators B: Chemical, 259, 1-9.

12. Jin, G., Xiao, X., Li, S., Zhao, K., Wu, Y., Sun, D. \& Wang, F. (2015). Strongly coupled graphene/ $\mathrm{Mn}_{3} \mathrm{O}_{4}$ composite with enhanced electrochemical performance for supercapacitor electrode. Electrochimica Acta, 178, 689-698.

13. Kan, X., Geng, Z., Zhao, Y., Wang, Z. \& Zhu, J. J. (2009). Magnetic molecularly imprinted polymer for aspirin recognition and controlled release. Nanotechnology, 20(16), 165601-165607.

14. Lahcen, A. A. \& Amine, A. (2019). Recent advances in electrochemical sensors based on molecularly imprinted polymers and nanomaterials. Electroanalysis, 31(2), 188-201.

15. Lata, K., Sharma, R., Naik, L., Rajput, Y. \& Mann, B. (2015). Synthesis and application of cephalexin imprinted polymer for solid phase extraction in milk. Food Chemistry, 184, 176-182.

16. Li, P., Wang, T., Lei, F., Tang, P., Tan, X., Liu, Z. \& Shen, L. (2014). Rosin-based molecularly imprinted polymers as the stationary phase in high-performance liquid chromatography for selective separation of berberine hydrochloride. Polymer International, 63(9), 1699-1706.

17. Malitesta, C., Di Masi, S. \& Mazzotta, E. (2017). From electrochemical biosensors to biomimetic sensors based on molecularly imprinted polymers in environmental determination of heavy metals. Frontiers in Chemistry, 5, 47-53.

18. Marć, M., Kupka, T., Wieczorek, P. P. \& Namieśnik, J. (2018). Computational modeling of molecularly imprinted polymers as a green approach to the development of novel analytical sorbents. TrAC Trends in Analytical Chemistry, 98, 64-78. 
19. Meier, F. \& Mizaikoff, B. (2010). Molecularly imprinted polymers as artificial receptors. Artificial Receptors for Chemical Sensors, 12, 391-437.

20. Momeneh, H. \& Gholivand, M. B. (2018). Mycophenolate mofetil sensor based on molecularly imprinted polymer/multi-walled carbon nanotubes modified carbon paste electrode. Analytical Biochemistry, 557, 97-103.

21. Rutkowska, M., Płotka-Wasylka, J., Morrison, C., Wieczorek, P. P., Namieśnik, J. \& Marć, M. (2018). Application of molecularly imprinted polymers in analytical chiral separations and analysis. TrAC Trends in Analytical Chemistry, 102, 91-102.

22. Tadi, K. K. \& Motghare, R. V. (2016). Voltammetric determination of pindolol in biological fluids using molecularly imprinted polymer based biomimetic sensor. Journal of The Electrochemical Society, 163(7), B286-B291.

23. Varghese, S. P., Babu, B., Prasannachandran, R., Antony, R. \& Shaijumon, M. (2019). Enhanced electrochemical properties of $\mathrm{Mn}_{3} \mathrm{O}_{4} /$ graphene nanocomposite as efficient anode material for lithium ion batteries. Journal of Alloys Compounds, 780, 588-596.

24. Zhang, N., Zhang, N., Xu, Y., Li, Z., Yan, C., Mei, K. \& Ding, M. (2019). Molecularly imprinted materials for selective biological recognition. Macromolecular Rapid Communications, 40(17), 1900096-1900101.

25. Zhang, Q., Zhu, Z. \& Ni, Y. (2020). Interaction between aspirin and vitamin C with human serum albumin as binary and ternary systems. Spectrochimica Acta Part A: Molecular Biomolecular Spectroscopy, 118356-118372. 